\title{
Fiscal Competition Among Local Governments: The Issue Of Municipal Overburden\#
}

\author{
Donald Elliott*
}

\section{INTRODUCTION}

The term "intergovernmental fiscal relations" usually brings to mind the partitioning or sharing of functions and revenues among a vertically ordered set of levels of government. The common vertical ordering used in the public finance literature is federal, state and local. However, increasing attention has been focused recently on the interaction among governments within a stratum.

This paper examines one set of hypotheses related to the interaction among local governments dependent upon a common property tax base. In measuring the fiscal capacity of one local government, the local revenue requirements of other governments are often taken into account. Thus, it is assumed that increased revenue demands by one local government significantly reduce the ability of other local governments to raise tax revenue. This is an empirically testable hypothesis.

In the school finance literature, this area of contention is now known as the issue of municipal overburden. Municipal overburden refers to situations in which the fiscal capacity of a school district, for instance, is reduced by the revenue requirements of other local governments dependent upon the same property tax base. ${ }^{1}$ Urban legislators, claiming that cities have extraordinarily high nonschool property tax burdens, argue that urban schools should receive extra state aid. Rural legislators refute this argument by pointing out that nonschool property taxes are, at least in part, an expression of voter demand for urban services, many of which are provided in rural areas through the private sector.

In this paper, neoclassical microeconomic theory is used to develop models allowing for the following two alternative formulations of the impact of municipal overburden:

(1) that the ability of the school district to raise tax revenue is significantly reduced by the revenue demands of other local governments regardless of the unit costs of nonschool services provided by these governments, or

\footnotetext{
\#The author wishes to thank O. H. Brownlee, Dennis Johnson, Jerry Hollenhorst and anonymous referees for helpful remarks on earlier drafts. A preliminary version of this paper was presented at the Western Economic Association Annual Meeting, June, 1977.

*Assistant Professor of Economics, Southern Illinois University at Edwardsville.
} 
(2) that the ability of the school district to raise tax revenue is significantly reduced only if the revenue demands of other local governments rise because of their increasing unit costs.

In the development of an empirical model to test for the impact of municipal overburden, it is demonstrated that:

(1) the absence of a theoretical model depicting the role of municipal overburden in the public choice process has resulted in the misspecification of estimating equations in previous literature addressing questions in this area,

(2) nonlinearities in the endogenous variables cause typical two-stageleast-squares estimates of structural parameters to be inconsistent in the most general test of the impact of municipal overburden,

(3) the ability of a school district to export property taxes may bear more significantly on this issue than previously realized.

The empirical section of the paper investigates the interaction between school and nonschool governments in Minnesota. In this sample, the hypothesized negative impact of municipal overburden is soundly rejected.

The development of a theoretical model of school and municipal public choice which allows for municipal overburden is outlined in Section I. A discussion of the econometric properties of various specifications and estimation procedures is presented in Section II. The data and empirical results may be found in Section III, and the conclusions and summary, in Section IV.

\section{SECTION I : THEORETICAL MODEL}

In this section, a theoretical model of the determination of school and nonschool ("municipal") governmental services is developed. The model incorporates the dependence of these local governments upon a common property tax base. Outcomes are assumed to be determined by majority voting without logrolling or other informationally expensive strategies.

TABLE 1

Notation

$$
\begin{aligned}
\mathrm{U}_{\mathrm{i}} & =\text { utility of the } \mathrm{i}^{\text {th }} \text { household } \\
\mathrm{E} / \mathrm{S} & =\text { educational services per pupil } \\
\mathrm{M} / \mathrm{H} & =\text { nonschool governmental services per household } \\
\mathrm{A}_{\mathrm{i}} & =\text { all other goods and services consumed by } \\
& \quad \text { the } \mathrm{i}^{\text {th }} \text { household } \\
\mathrm{p}_{\mathrm{E}}= & \text { unit cost of educational services } \\
\mathrm{p}_{\mathrm{M}}= & \text { unit cost of nonschool services } \\
\mathrm{p}_{\mathrm{A}} & =\text { price of all other goods and services }
\end{aligned}
$$


TABLE 1 (cont.)

$v_{i}=$ market value of property owned by $i^{\text {th }}$ household

$Y_{i}=$ income of $i^{\text {th }}$ household

$\mathrm{V}=$ total market value of all property in school district

$\mathrm{G}_{\mathrm{E}}=$ educational grants

$\mathrm{G}_{\mathrm{M}}=$ nonschool grants

$t_{E}=$ effective property tax rate for education

$t_{M}=$ effective property tax rate for nonschool services

$\mathrm{X}_{\mathrm{E}} / \mathrm{S}=$ educational expenditure per pupil

$\mathrm{X}_{\mathrm{M}} / \mathrm{H}=$ nonschool expenditure per household

Let:

(1.1) $\mathrm{U}_{\mathrm{i}}=\mathrm{U}_{\mathrm{i}}\left(\mathrm{A}_{\mathrm{i}}, \mathrm{E} / \mathrm{S}, \mathrm{M} / \mathrm{H}\right) .^{2}$

The budget constraint of the $\mathrm{i}^{\text {th }}$ household is:

$$
p_{A} A_{i}+t_{E} v_{i}+t_{M} v_{i} \leq Y_{i}
$$

If local governments are required to balance their budgets, then the budget constraints on schools and municipalities require that the effective property tax rates be set according to:

(1.3) $t_{\mathrm{E}}=\left(\mathrm{X}_{\mathrm{E}}-\mathrm{G}_{\mathrm{E}}\right) / \mathrm{V}$

(1.4) $\mathrm{t}_{\mathrm{M}}=\left(\mathrm{X}_{\mathrm{M}}-\mathrm{G}_{\mathrm{M}}\right) / \mathrm{V}$, $^{3}$

where $\mathrm{X}_{\mathrm{E}}=(\mathrm{E} / \mathrm{S}) \mathrm{S} \mathrm{p}_{\mathrm{E}}$ and $\mathrm{X}_{\mathrm{M}}=(\mathrm{M} / \mathrm{H}) \mathrm{Hp}_{\mathrm{M}}$.

If the household recognizes the budget constraints faced by the local governments in its own utility maximization, then we can restate the household budget constraint in terms of the arguments of the household utility functions:

$$
\begin{aligned}
& \mathrm{p}_{\mathrm{A}} \mathrm{A}_{\mathrm{i}}+\left[(\mathrm{E} / \mathrm{S})\left(\mathrm{Sp}_{\mathrm{E}}\right)-\mathrm{G}_{\mathrm{E}}\right]\left[\mathrm{v}_{\mathrm{i}} / \mathrm{V}\right]+\left[(\mathrm{M} / \mathrm{H})\left(\mathrm{Hp}_{\mathrm{M}}\right)-\mathrm{G}_{\mathrm{M}}\right] \\
& {\left[\mathrm{v}_{\mathrm{i}} / \mathrm{V}\right] \leq \mathrm{Y}_{\mathrm{i}} \text {. }}
\end{aligned}
$$

Maximizing (1.1) subject to (1.5), the demand functions of the $\mathrm{i}^{\text {th }}$ household for educational and municipal services are:

$$
\begin{aligned}
& (E / S)_{i}=D_{i}^{E}\left[Y_{i}, S_{p_{E}}\left(v_{i} / V\right), H_{M}\left(v_{i} / V\right), p_{A}, G_{E}\left(v_{i} / V\right), G_{M}\left(v_{i} / v\right)\right] \\
& (M / H)_{i}=D_{i}^{M}\left[Y_{i}, S_{E}\left(v_{i} / V\right), H p_{M}\left(v_{i} / V\right), p_{A}, G_{E}\left(v_{i} / V\right), G_{M}\left(v_{i} / V\right)\right] .
\end{aligned}
$$


(1.6) states that the $\mathrm{i}^{\text {th }}$ household's demand for educational services per pupil depends upon its income, the marginal tax price for educational services per pupil, the marginal tax price of municipal services per pupil, the price of other goods and services, and the tax relief granted to the household by grants to municipalities and school districts. (1.7) makes an analogous statement about the $i^{\text {th }}$ household's demand for municipal services.

Suppose that each household in the district performs such a utility maximization. Household demand functions would vary across households even if income and property were uniformly distributed. Such differences in demands might be caused by differences in tastes or differences in ability to benefit from public services. For example, households with identical incomes and property may differ in their demands for educational services according to the levels of education attained by the heads of the households or according to the number of school-aged children in each household. In the remaining sections of this paper, variables reflecting household characteristics associated with such differences in marginal valuation of public services will be subsumed under the label "tastes."

After ranking the household demands for each service, the median demands are selected as the outcomes under majority rule. Let m denote the median voter in each of the rankings.

$$
\begin{aligned}
(E / S)_{m}= & D^{E}\left[Y_{m}, S_{E}\left(v_{m} / V\right), H_{M}\left(v_{m} / V\right), p_{A}, G_{E}\left(v_{m} / V\right),\right. \\
& \left.G_{M}\left(v_{m} / V\right), \text { tastes }\right] \\
(M / H)_{m}= & D^{M}\left[Y_{m}, S_{p_{E}}\left(v_{m} / V\right), H_{M}\left(v_{m} / V\right), p_{A}, G_{E}\left(v_{m} / V\right),\right. \\
& \left.G_{M}\left(v_{m} / V\right), \text { tastes }\right]
\end{aligned}
$$

From (1.8) and (1.9), several important observations can be made:

(a) the outcomes from the majority voting process depend strongly upon the relationships among the distribution of household income, the distribution of locally owned property, and tastes,

(b) the median voter for one type of government service is highly unlikely to be the median voter for the other service,

(c) the level of expenditure for one government service does not appear directly in the demand for the other.

The ranking of the respective demands is likely to depend strongly upon median district income, median value of household property, median educational attainment of parents, family size, etc. But there is no assurance that the median voter for a particular service possesses all these median values for income, property, education, etc. For example, in rural districts with small towns and successful farms, the median voter for educational services may have less than the median number of children, less than the median property value, and less than the median household 
income. In this case, both household income and property may appear to be inversely related to educational demand. This is caused by the high marginal tax price of educational services per pupil to the property-rich farm households.

Because households' relative positions in the rankings for the two services are likely to vary, ${ }^{4}$ it is highly doubtful that the same household will find itself to be the decisive, median voter in both rankings. If households realize this and assume that they can influence at most one of the services, then the demand functions will contain different arguments from those appearing in (1.8) and (1.9). We shall return to this possibility later.

Most importantly, note that when households maximize utility simultaneously with respect to both types of services, the arguments which appear in the demand functions are the marginal tax prices for the services and not the levels of expenditure or taxes levied. That is, the demand for educational services per pupil depends upon the cost of an additional unit of municipal services per household to the median voter in the education ranking. Tax levels are endogenous to the household's decision process. ${ }^{5}$ Demand for educational services depends upon the household's income before local taxes and not its net income after local taxes. In this formulation of the model, the impact of municipal overburden must be interpreted as the influence of the marginal tax price of municipal services upon the demand for educational services. However, this influence can take two forms. A high marginal tax price for municipal services could have a strong income effect which would adversely affect educational demand or an overriding substitution effect which might strengthen the demand for educational services. The dominance of the income effect is consistent with the usual municipal overburden argument; the dominance of the substitution effect is not. Because municipal services are frequently regarded as necessities, advocates of the municipal overburden argument will contend that the substitution effect is negligible while the income effect may be significant, especially in large metropolitan areas where population density aggravates external diseconomies. For example, if population density is associated with greater fire hazard, then the incremental cost per household for fire protection is greater in center cities than in suburbs. ${ }^{6}$ Similar arguments can be made for police protection, traffic control, and health programs. Because the benefits of such municipal services may be more widespread among the electorate than benefits from school services, support for schools may be adversely affected by high unit-costs for the municipal services.

Thus far, the analysis follows traditional microeconomic theory in that the household is assumed to determine simultaneously the amounts of public education and local services that it wishes to consume. Note that the revenue requirement of one local government does not appear in the demand relationship for the other; the primary interaction explicit in this formulation occurs through the inclusion of the marginal tax price of one government in the demand relationship for the services of the other. This 
is not the type of interaction explicitly cited in most verbal treatments of municipal overburden.

Is this assumed behavior of the simultaneous determination of the household's desired expenditures on public education and local services realistic under the institutional arrangement through which these services are provided? Or does the household determine its demand for local nonschool services given the level of educational expenditure and taxes which it confronts as outcomes of the majority-voting process? And, similarly, does the household determine its demand for educational expenditure conditionally upon the mandated levels of local nonschool services and taxes? If so, the household demand functions should be different from those just derived.

If in determining its demand in one sector the household does indeed view the outcomes of the other sector as given, then the utility maximization problem of the household consists of two suboptimizations:

(1.10) $\operatorname{Max} \mathrm{U}_{\mathrm{i}}=\mathrm{U}_{\mathrm{i}}\left[\mathrm{A}_{\mathrm{i}}, \mathrm{M} / \mathrm{H} ; \tilde{\mathrm{E}} / \mathrm{S}\right]$ subject to $\mathrm{p}_{\mathrm{A}} \mathrm{A}+[(\tilde{\mathrm{E}} / \mathrm{S})$ $\left.\left(\mathrm{Sp}_{\mathrm{E}}\right)-\mathrm{G}_{\mathrm{E}}\right]\left[\mathrm{v}_{\mathrm{i}} / \mathrm{V}\right]+\left[(\mathrm{M} / \mathrm{H})\left(\mathrm{Hp}_{\mathrm{M}}\right)-\mathrm{G}_{\mathrm{M}}\right]\left[\mathrm{v}_{\mathrm{i}} / \mathrm{V}\right] \leqslant \mathrm{Y}_{\mathrm{i}}$

(1.11) $\operatorname{Max} U_{i}=U_{i}\left[A_{i}, E / S ; \tilde{M} / H\right]$ subject to $\mathrm{p}_{A} A+\lceil(E / S)$ $\left.\left(\mathrm{Sp}_{\mathrm{E}}\right)-\mathrm{G}_{\mathrm{E}}\right]\left[\mathrm{v}_{\mathrm{i}} / \mathrm{V}\right]+\left[(\tilde{\mathrm{M}} / \mathrm{H})\left(\mathrm{Hp}_{\mathrm{M}}\right)-\mathrm{G}_{\mathrm{M}}\right]\left[\mathrm{v}_{\mathrm{i}} / \mathrm{V}\right] \leqslant \mathrm{Y}_{\mathrm{i}}$,

where $\tilde{\mathrm{E}} / \mathrm{S}$ and $\tilde{\mathrm{M}} / \mathrm{H}$ are the anticipated outcomes of the referenda for the two sets of services. These may be based on naive, adaptive, or rational expectations. For simplicity, assume that the household uses $(\tilde{\mathrm{E}} / \mathrm{S})_{\mathrm{t}}=(\mathrm{E} /$ $\mathrm{S})_{\mathrm{t}-1}$ and $(\tilde{\mathrm{M}} / \mathrm{H})_{\mathrm{t}}=(\mathrm{M} / \mathrm{H})_{\mathrm{t}-1}$. The demand functions corresponding to these suboptimizations are:

$$
\begin{aligned}
& (E / S)_{i}=D_{i}^{E}\left[Y_{i}, \operatorname{Sp}_{E}\left(v_{i} / V\right),\left(H p_{M} \tilde{M} / H-G_{M}\right)\left(v_{i} / V\right), p_{A}, G_{E}\left(v_{i} / V\right)\right] \\
& (M / H)_{i}=D_{i}^{M}\left[Y_{i},\left(\operatorname{Sp}_{E} \tilde{E} / S-G_{E}\right)\left(v_{i} / V\right), H p_{M}\left(v_{i} / V\right), p_{A}, G_{M}\left(v_{i} / V\right)\right]
\end{aligned}
$$

Or, more simply:

$$
\begin{aligned}
& (E / S)_{i}=D_{i}^{E}\left[Y_{i}, \operatorname{Sp}_{E}\left(v_{i} / V\right), \tilde{t}_{M} v_{i}, p_{A}, G_{E}\left(v_{i} / V\right)\right] \\
& (M / H)_{i}=D_{i}^{M}\left[Y_{i}, \tilde{t}_{E} v_{i}, H p_{M}\left(v_{i} / V\right), p_{A}, G_{M}\left(v_{i} / V\right)\right]
\end{aligned}
$$

Notice that the demand relation for local services now depends upon the expenditure on education; this dependence takes the form of the tax burden borne by the household to support local public education. Similarly, the demand relation for educational expenditure now depends upon the expenditure or tax burden in the local service sector. Therefore, this formulation with conditional optimization of the household's utility function does allow for the type of interaction implicit in most of the literature on municipal overburden.

Again, the household demand functions are used to derive the market 
demand functions. Once again the assumption of representative government is applied with respect to the provision of local services so that the market outcomes should be determined by majority voting. Under this process, the household demands are ranked and the median demand prevails. Under an assumption that $\mathrm{t}_{\mathrm{M}}$ and $\mathrm{p}_{\mathrm{M}}$ are constant within a school district, ${ }^{7}$ the district demand relations are:

$$
\begin{aligned}
& (E / S)_{m}=D^{E}\left[Y_{m}, \operatorname{Sp}_{E}\left(v_{m} / V\right), \tilde{t}_{M} v_{m}, p_{A}, G_{E}\left(v_{m} / V\right), \text { tastes }\right] \\
& (M / H)_{m}=D^{M}\left[Y_{m}, \tilde{t}_{E} v_{m}, H p_{M}\left(v_{m} / V\right), p_{A}, G_{M}\left(v_{m} / V\right), \text { tastes }\right],
\end{aligned}
$$

where the m subscripts again denote the median voter in the respective rankings. Also note that if each of the median voters for the two sectors reacts to the other's mandated expenditure, then $t_{E}$ and $t_{M}$ will change over time. The ultimate equilibrium will be similar to that in oligopoly models using reaction functions. In the estimations below, it is assumed that each district has reached such an equilibrium.

\section{SECTION II : SPECIFICATION AND ESTIMATION}

In the application of the model described in (1.16) and (1.17), one confronts two major estimation problems: the measurement of $\mathrm{E} / \mathrm{S}, \mathrm{M} / \mathrm{H}$, $\mathrm{p}_{\mathrm{E}}$, and $\mathrm{p}_{\mathrm{M}}$, and a system of simultaneous equations which is nonlinear in the endogenous variables.

With respect to the measurement problems, two options are available. One could attempt to develop qualitative measures of $\mathrm{E} / \mathrm{S}$ and $\mathrm{M} / \mathrm{H}$ and their corresponding prices. ${ }^{8}$ Or, as I have argued elsewhere, use $\mathrm{X}_{\mathrm{E}} / \mathrm{S}$ and $\mathrm{X}_{\mathrm{M}} / \mathrm{H}$ deflated for interdistrict cost differentials. ${ }^{9}$

The problem of nonlinearity has not been addressed previously in the public finance literature on municipal overburden or related topics. However, its existence suggests potentially serious implications for the empirical work being done. A currently popular model of housing value is usually formulated in terms of the interdependence of local municipal services (or expenditure), local school services (or expenditure), the effective property tax rate, and median value of residential property. ${ }^{10}$

In the notation of this paper, the system referred to above may be specified as: ${ }^{11}$

(2.1) $\quad \mathrm{E} / \mathrm{S}=\mathrm{D}^{\mathrm{E}}\left[\mathrm{M} / \mathrm{H}, \mathrm{t}_{\mathrm{E}}+\mathrm{t}_{\mathrm{M}}, \mathrm{v}_{\mathrm{m}}, \ldots\right]$

(2.2) $\mathrm{M} / \mathrm{H}=\mathrm{D}^{\mathrm{M}}\left[\mathrm{E} / \mathrm{H}, \mathrm{t}_{\mathrm{E}}+\mathrm{t}_{\mathrm{M}}, \mathrm{v}_{\mathrm{m}}, \ldots\right]$

(2.3) $\mathrm{t}_{\mathrm{E}}+\mathrm{t}_{\mathrm{m}}=\left[\mathrm{Hp}_{\mathrm{M}}(\mathrm{M} / \mathrm{H})-\mathrm{G}_{\mathrm{M}}+\mathrm{Sp}_{\mathrm{E}}(\mathrm{E} / \mathrm{S})-\mathrm{G}_{\mathrm{E}}\right] / \mathrm{V}$

(2.4) $\mathrm{v}_{\mathrm{m}}=\mathrm{F}\left[\mathrm{M} / \mathrm{H}, \mathrm{E} / \mathrm{S}, \mathrm{t}_{\mathrm{E}}+\mathrm{t}_{\mathrm{m}}, \ldots\right]$.

Note that the tax price or municipal overburden terms in (2.1) and (2.2) are misspecified. Furthermore, (2.3) demonstrates the nonlinear fashion 
in which the average effective tax rate depends upon the other endogenous variables if $\mathrm{V}$ and $\mathrm{v}_{\mathbf{i}}$ are strongly related as may frequently occur in a metropolitan sample.

According to the theory developed in Section I, the appropriate specification would be: ${ }^{2}$

$$
\begin{array}{ll}
(2.5) & \mathrm{E} / \mathrm{S}=\mathrm{D}^{\mathrm{E}}\left[\mathrm{Y}_{\mathrm{m}}, \mathrm{Sp}_{\mathrm{E}}\left(\mathrm{v}_{\mathrm{m}} / \mathrm{V}\right), \mathrm{t}_{\mathrm{M}} \mathrm{v}_{\mathrm{m}} \mathrm{p}_{\mathrm{A}}, \mathrm{G}_{\mathrm{E}}\left(\mathrm{v}_{\mathrm{m}} / \mathrm{V}\right), \ldots\right] \\
(2.6) & \mathrm{M} / \mathrm{H}=\mathrm{D}^{\mathrm{M}}\left[\mathrm{Y}_{\mathrm{m}}, \mathrm{t}_{\mathrm{E}} \mathrm{V}_{\mathrm{m}}, \mathrm{Hp}_{\mathrm{M}}\left(\mathrm{v}_{\mathrm{m}} / \mathrm{V}\right), \mathrm{p}_{\mathrm{A}}, \mathrm{G}_{\mathrm{M}}\left(\mathrm{v}_{\mathrm{m}} / \mathrm{V}\right), \ldots\right] \\
(2.7) & \mathrm{t}_{\mathrm{E}}=\left[\mathrm{Sp}_{\mathrm{E}} \mathrm{E} / \mathrm{S}-\mathrm{G}_{\mathrm{E}}\right] / \mathrm{V} \\
(2.8) & \mathrm{t}_{\mathrm{M}}=\left[\mathrm{H} \mathrm{p}_{\mathrm{M}} \mathrm{M} / \mathrm{H}-\mathrm{G}_{\mathrm{M}}\right] / \mathrm{V} \\
(2.9) & \mathrm{v}_{\mathrm{m}}=\mathrm{F}\left[\mathrm{E} / \mathrm{S}, \mathrm{M} / \mathrm{H}, \mathrm{t}_{\mathrm{E}}, \mathrm{t}_{\mathrm{M}}, \ldots\right]
\end{array}
$$

How serious is the misspecification in $(2.1)-(2.4)$ ? The equation of primary interest in most studies using this type of model has been (2.4). Because there is little reason to believe that the other endogenous variables enter this equation nonlinearly, two-stage least squares may be applied. However, if the structural parameters of (2.1) and (2.2), are of primary concern, then the typical two-stage least squares estimators will be inconsistent. ${ }^{13}$ However, all is not lost. Kalejian [6] demonstrates that a modified two-stage least squares procedure using a polynomial regression to instrument the nonlinear forms will yield consistent estimates. Because the question of municipal overburden is directly related to (2.1) and (2.2), this is the procedure which must be applied in a test of this hypothesis.

The model presented in Section I also calls into question the results of other empirical studies in the literature. For example, Weicher [13] and Marsh [7] analyze the influence of grants to one sector upon expenditures of another. However, neither includes taxes for one directly in the equation for services of the other. ${ }^{14}$ Waldauer [12] performs a similar analysis in looking at the impact of school aid upon municipal expenditures. Andrew, Sacks, et al [1] examine the relationship between expenditures of school and nonschool governments but fail to use a simultaneous equation technique. Treacy and Harris [11] examine metropolitan data for Ohio and are unable to support the municipal overburden hypothesis. But, except for enrollment and property value, their study fails to hold constant other variables which might influence this relationship.

\section{SECTION III : DATA AND EMPIRICAL RESULTS}

The data used in this study are observations on 345 Minnesota school districts for the academic year $1970-71 .{ }^{15}$ Table 2 depicts the results from three alternative estimations of equation (2.5). The first set of estimates were obtained using ordinary least squares with identity (2.8) determining $t_{M}$. The second set of estimates were obtained using traditional two-stage least squares. The third set of estimates were derived from two-stage least squares using polynomially instrumented endogenous variables. ${ }^{16}$ 
TABLE 2

Coefficient Estimates For School Services

\begin{tabular}{|c|c|c|c|c|c|c|}
\hline \multirow{2}{*}{$\frac{\text { Variable }}{\text { Median Household Income }}$} & \multicolumn{2}{|c|}{ Ordinary Least Squares } & \multicolumn{2}{|c|}{ Traditional 2SLS } & \multicolumn{2}{|c|}{ Quadratic 2SLS } \\
\hline & .00147 & $(.00264)$ & .00584 & $(.0124)$ & .00250 & $(.00300)$ \\
\hline Marginal Tax Price $\left[S p_{E} v_{R} / V\right]$ & $-1.99 * * *$ & $(.343)$ & -2.67 & $(4.64)$ & $-2.78 * * *$ & $(.531)$ \\
\hline Marginal Tax Price $\left[\mathrm{Sp}_{\mathrm{E}} \mathrm{v}_{\mathrm{F}} / \mathrm{V}\right]$ & $-1.00 * * *$ & $(.135)$ & -.0455 & $(.761)$ & $-.906^{* * *}$ & $(.179)$ \\
\hline Marginal Tax Price $\left[\mathrm{Sp}_{\mathrm{E}} \mathrm{v}_{\mathrm{I}} / \mathrm{V}\right]$ & .212 & $(.795)$ & -1.52 & $(1.35)$ & $2.81^{* *}$ & $(1.38)$ \\
\hline $\begin{array}{l}\text { Muni Overburden } \\
{\left[\left(\mathrm{X}_{M}-\mathrm{G}_{M}\right) \mathrm{v}_{\mathrm{P}} / \mathrm{V}\right]}\end{array}$ & $.00434 * * *$ & $(.000737)$ & .00326 & $(.00910)$ & $.00589 * * *$ & $(.00110)$ \\
\hline $\begin{array}{l}\text { Muni Overburden } \\
{\left[\left(X_{M}-G_{M}\right) v_{F} / V\right]}\end{array}$ & $.00233 * * *$ & $(.000273)$ & .00102 & $(.00183)$ & $.00208 * * *$ & $(.000438)$ \\
\hline $\begin{array}{l}\text { Muni Overburden } \\
\qquad\left[\left(\mathrm{X}_{M}-\mathrm{G}_{M}\right) \mathrm{v}_{\mathrm{I}} / \mathrm{V}\right]\end{array}$ & -.0000620 & $(.00162)$ & .00713 & $(.00284)$ & $-.00471^{*}$ & $(.00293)$ \\
\hline $\begin{array}{l}\text { Percent of Pupils in } \\
\text { Private Schools }\end{array}$ & $-1.74^{* *}$ & $(.857)$ & $-2.12 *$ & $(1.16)$ & $-1.81 * *$ & $(.876)$ \\
\hline $\begin{array}{l}\text { Percent of Fathers with } \\
\text { Less Than } \\
\text { High School Diploma }\end{array}$ & $-1.33 * * *$ & $(.303)$ & $-1.64^{*}$ & $(.857)$ & $-1.37 * * *$ & $(.328)$ \\
\hline State Aid Per Pupil & $.330 * * *$ & $(.0515)$ & .222 & $(.152)$ & $.313 * * *$ & $(.0611)$ \\
\hline Federal Aid Per Pupil & $1.22 * * *$ & $(.170)$ & $1.29 * * *$ & $(.237)$ & $1.24 * * *$ & $(.175)$ \\
\hline Salary Burden Index & $-624 . * * *$ & $(26.5)$ & $-636 . * * *$ & $(50.1)$ & $-634 . \quad * * *$ & $(27.5)$ \\
\hline Constant & 1289. $* * *$ & $(45.4)$ & 1390. $* * *$ & $(76.6)$ & $1301 . * * *$ & $(47.9)$ \\
\hline $\mathrm{R}^{2}$ Adjusted For D.F. & .69 & & & & & \\
\hline
\end{tabular}

( ) Contain Standard Errors of Regression Coefficients. 
The dependent variable in all three estimations was adjusted maintenance expenditures per pupil unit deflated by a cost index. Adjusted maintenance expenditure is a measure of current operating expense and excludes capital and transportation expenditures. A pupil unit, as defined by the Minnesota State Office of Education, is a measure of enrollment in which the head count is weighted by an estimate of the relative cost of instruction by grade. Under this measure, a high school student is assigned a weight greater than unity, and a kindergarten pupil is assigned a weight less than unity. The cost index corrects for variation in instructional expense caused by differing tenure densities across districts. The index reflects differences in salary burdens attributable to the reduced staffing flexibility in districts with stagnant or declining enrollments. The index also appears as an independent variable representing relative unit costs across districts. This specification is analogous to the inclusion of price as an independent variable in a demand equation when the dependent variable is deflated sales. ${ }^{17}$

Voters' demands for services financed through property taxes will be influenced by the extent to which their tax burden which can be exported. $\mathrm{v}_{\mathrm{m}} / \mathrm{V}$, which appears in the marginal tax price and municipal overburden terms, is represented by weighted property class shares:

$\mathrm{v}_{\mathrm{R}} / \mathrm{V}$ is the average share per household of total district market value classified as residential;

$\mathrm{v}_{\mathrm{F}} / \mathrm{V}$ is the share classified as agricultural, seasonal or recreational;

$$
\mathrm{v}_{\mathrm{I}} / \mathrm{V} \text { is the property share classified as industrial or commercial. }
$$

The sum of $v_{R}$ and $v_{F}$ is probably closely correlated with the percentage of district property wealth that is locally owned. Industrial, commercial or utility property is less likely to be locally owned, and thus the local property tax on these classes may be exported to nonlocal owners. Or, if the property tax on these classes results in excise tax effects on the services which they produce, these excise tax effects may not be borne by local residents. A one-unit increase in $\left(\mathrm{X}_{\mathrm{M}}-\mathrm{G}_{\mathrm{M}}\right) \mathrm{v}_{\mathrm{R}} / \mathrm{V}$ is a one-dollar increase in municipal property taxes on household residential property. Consequently, the regression coefficient for $\left(\mathrm{X}_{\mathrm{M}}-\mathrm{G}_{\mathrm{M}}\right) \mathrm{v}_{\mathrm{R}} / \mathrm{V}$ may be interpreted as the effect of a one dollar increase in residential municipal property taxes per household on deflated expenditure per pupil. If the hypothesis regarding the adverse impact of municipal overburden upon school finance is true, the coefficients of $\left(X_{M}-G_{M}\right) v_{R} / V$ and $\left(X_{M}-G_{M}\right) v_{F} / V$ should be significantly negative. However, the sign of $\left(\mathrm{X}_{\mathrm{M}}-\mathrm{G}_{\mathrm{M}}\right) \mathrm{v}_{\mathrm{I}} / \mathrm{V}$ cannot be predicted. If industrial and commercial property taxes are exported, municipal taxes levied on this property class may have no impact upon school finance, even under the municipal overburden hypothesis. The signs of marginal tax price coefficients permit a more direct check on tax incidence and exporting. $A$ priori, one would expect the coefficients of the tax price terms related to $\mathrm{v}_{\mathrm{R}}$ and $v_{F}$ to be negative and the coefficient related to $v_{I}$ to be positive. 
Examination of the regression coefficients in Table 2 reveals no support for the municipal overburden hypothesis. ${ }^{18}$ In fact, $T$ tests of the $v_{R}$ and $v_{F}$ municipal overburden coefficients in both the ordinary least-squares and quadratic two-stage least-squares estimations emphatically reject the onetailed test that any one of these coefficients is negative. The municipal overburden hypothesis is usually interpreted as implying that both of these coefficients are negative. The quadratic two-stage estimation reinforces the pattern cited previously in the literature - a strong positive relationship between school and nonschool expenditure even after the influence of other important determinants has been taken into account.

The quadratic two-stage results indicate a mixed pattern of tax exporting. The significant, positive coefficient for the marginal tax burden on industrial and commercial property supports the hypothesis that school property taxes are exported. However, the negative coefficient for the industrial municipal overburden term would appear to support either internalization of the tax burden from nonschool property taxes or voter recognition of possible commercial and industrial tax base flight. But note that the coefficient of this term is significantly different from zero only if the ten percent significance level is used.

Other regressions were run to test the influence of the teacher salary burden index on locally funded nonschool expenditures. This might be called a "school overburden" hypothesis and measures the impact of unitcost differentials across school districts on nonschool spending. Again, the hypothesis of "burden" was rejected as the coefficient of the index term was not significantly different from zero. No data were available to test the impact of cost differentials across nonschool governments on school spending.

What possible explanations may be suggested for the persistent positive relationship between school and nonschool expenditure in the literature? One possibility is that communities formed in the Tiebout process tend to reflect either strong support for all government services or weak support for all government services, but rarely strong support for one service accompanied by weak support for another. Implicit in this hypothesis is the presumption that the influence of taste variables which cause such a partitioning of communities has not been adequately captured in empirical studies up to this time. If such misspecification caused by omission of civic-oriented taste variables were strong enough, any impact of municipal overburden would be extremely difficult to detect. Furthermore, arguments for additional aid to offset municipal overburden would be considerably weaker under these circumstances, since the voter distribution would be much more homogeneous with respect to desired expenditures. The maxima from suboptimizations (1.10) and (1.11) might not differ significantly from maxima generated by simultaneous optimization in (1.6) and (1.7).

The positive correlation would be even stronger if attempted tax exporting resulted in tax base flight. If commercial and industrial property should tend to flee Tiebout communities with strong support for government services, then communities with above average values for municipal 
expenditure would be left with higher than average locally-owned property shares and lower than average property bases. But these same communities would still support higher than average school expenditure. It is highly probable that such a Tiebout world would be unstable, as citizens seeking fiscal surpluses form high-support Tiebout communities around industrial and commercial tax base, only to have that industrial and commercial base flee to low-support Tiebout communities.

\section{SECTION IV: CONCLUSIONS}

Although theoretical justification for the municipal overburden argument can be developed from a public choice model, no empirical support was found in tests in a sample of Minnesota school districts. Two hypotheses regarding the impact of municipal overburden were tested: (1) that the ability of a school district to raise local tax revenue is significantly reduced by the revenue demands of other tax-base sharing local governments regardless of the differences in unit-costs of services provided by these other governments and (2) that the ability of one government to raise local tax revenue is adversely affected by higher unit-costs for the services of another local government. The second hypothesis was tested only in the form of higher school instructional costs impeding the financing of nonschool services.

Because of nonlinearities in the simultaneous equation specification, traditional two-stage least squares estimation of the structural parameters of municipal overburden models will yield inconsistent estimates. A polynomially instrumented first stage estimation may be used to overcome this difficulty, but at the expense of requiring a much larger sample and possible aggravation of multicollinearity among the exogenous variables. In order to obtain sufficient degrees of freedom, the Minnesota sample contained a higher percentage of rural districts than one would desire in an optimal test of municipal overburden. Thus, generalization of the empirical results of this paper should be undertaken with care.

A possible explanation of the persistent positive relationship between school and nonschool spending which pervades the literature in this area might be found in an extension of the Tiebout hypothesis. Such a positive correlation would exist if the majority of communities thus formed were characterized by either strong support for all local governmental services or weak support for all local services, rather than mixes strongly biased toward one service or the other. Under these circumstances, detection of any adverse impact from municipal overburden would be possible only if taste variables accounting for such civic homogeneity were adequately captured in the empirical model. However, in this case, the burdens created by high nonschool tax rates would have to be viewed as voluntary user fees. Thus, any argument for compensatory state aid to the affected school districts would be easily refuted.

At this time, state legislatures should be advised to withstand pressures for additional aid to urban schools based on the minicipal overburden argument. In the absence of empirical evidence to support such claims, 
other uses of state educational revenues should be given priority. If urban nonschool tax rates are considered excessive, legislatures should evaluate the need for direct state subsidies to the governments providing these services and not attack such problems indirectly by incorporating unsupported weights into formulae for state school aid.

\section{FOOTNOTES}

1. See Treacy and Harris [11] and Brazer et al. [2] for extensive references on municipal overburden.

2. If one considers municipal services to be pure public goods, then $\mathrm{M}$ rather than $\mathrm{M} / \mathrm{H}$ should appear here. The extension of the theory to the case of pure public goods is straightforward and does not significantly alter the analysis.

3. For simplicity, $G_{E}$ and $G_{M}$ are assumed to be lumpsum grants. This assumption is valid for the 1970-71 Minnesota Foundation Aid grant which was the main state aid program for elementary and secondary education. The assumption is less likely to hold in the case of federal school aid and nonschool grants. $\mathbf{v}_{\mathbf{i}}$ and $\mathrm{V}$ are assumed to be exogenous thus far. This assumption is relaxed in the empirical model developed in Section II

4. For example, it is unlikely that a retired household will receive significant benefits from educational services, but it may staunchly support municipal services.

5. Tax levels here are analogous to expenditure in the textbook case of utility maximization with respect to private consumption

6. Economies of scale may reverse this pattern in comparing rural areas with suburbs.

7. This assumption is likely to fail in school districts which are not coterminous with municipalities. The degree of variation in $t_{M}$ is correlated with the degree of heterogeneity of the school district in terms of the distribution of households among incorporated and unincorporated areas. In this case, the distribution of $t_{M}$ across the population will affect the ranking of educational demands.

8. See McDougall [8].

9. Elliott [4] and [3]

10. For example, McDougall [8] or Oates [9].

11. Equation (2.3) is an identity, while equations (2.1), (2.2) and (2.4) are stochastic. Oates use of a logarithmic specification eliminates some of the nonlinearities. Also, $v_{M}$ in thsi literature is median property value rather than the property of the median voter.

12. Equations (2.7) and (2.8) are identities, while equations (2.5), and (2.6) and (2.9) are stochastic.

13. Kalejian [6].

14. Marsh [7] does test for interdependence using three-state least squares.

15. Districts involved in mergers, containing Indian reservations, or characterized by extensive mineral properties (Iron Range) were excluded from the sample. Districts involved in merger could not be considered in equilibrium. Districts containing Indian reservations or extensive iron-mining properties receive revenues that are vastly different from revenue sources of other districts. It was decided that to include such districts might reveal less about municipal overburden than an examination of districts relying more heavily on classical revenue sources.

16. Endogenous variables were instrumented using a quadratic form for the exogenous variables. The main disadvantages of such a procedure are the large dimensions of the matrix to be inverted for the relatively few exogenous variables in the system and aggravation of multicollinearity among the exogenous variables included in the first stage.

17. See Elliott [4] for a discussion of the cost index and econometric specification.

18. Both linear and logarithmic specifications are common in expenditure studies, and there seems little reason to prefer one over the other. A logarithmic specification would remove nonlinearities associated with the price and municipal overburden terms. A linear specification seems more appropriate if property-class shares are to be used to investigate tax exporting and relative burdens.

\section{REFERENCES}

1. Andrew, Ralph and Seymour Sacks, et al. "Competition Between Local School and Nonschool Functions for Property Tax Base," Eleventh Annual Conference on Taxation, Resources and Economic Development, October, 1972.

2. Brazer, Harvey, et al. "Fiscal Needs and Resources: A Report to the New York State Commission on the Quality, Cost and Financing of Elementary and Secondary Education" (November 1971; processed), Chap. 5.

3. Elliott, Donald. The Determination of Primary and Secondary Education Expenditure from Minnesota School Districts' Oun Sources, 1970-71. Unpublished PhD dissertation, University of Minnesota, 1976.

4. Elliott, Donald. "A Model of School Finance with Tenure Impactment Differentials," manuscript

5. Fisher, Franklin. The Identification Problem in Econometrics, New York: McGraw-Hill, 1966
6. Kalejian, Harry. "Two-Stage Least Squares and Econometric Systems Linear in Parameters but Nonlinear in the Endogenous Variables." Journal of the American Statistical Association (June, 1971), pp. 373-74.

7. Marsh, Lawrence C. "Weicher's State Aid and Local Expenditures Model and the Simultaneous Equations Controversy," National Tax Journal (Dec., 1975), pp. $459-461$.

8. McDougall, Gerald. "Local Public Goods and Residential Property Values: Some Insights and Extensions," National Tax Journal (Dec. 1976), pp. 436-447.

9. Oates, Wallace. "The Effects of Property Taxes and Local Public Spending on Property Values: An Empirical Investigation," Journal of Political Economy (Dec., 1969), pp. 957-971.

10. Oates, Wallace. "The Effects of Property Taxes and Local Public Spending: A Reply," Journal of Political 
Economy (Dec., 1973), pp. 1004-1008.

11. Treacy, John J. and Russell L. Harris. "Contemporary Suburban Schools-The Needy?" Southern Economic Journal (Apr., 1974), pp. 640-646.

12. Waldauer, Charles. "Fiscal Interdependence Among Tax Base-Sharing Local Governments:
The External Effects of School Aid," National Tax Journal (Dec., 1970), pp. 457-461.

13. Weicher, John C. "Aid, Expenditures, and Local Government Structure," National Tax Journal (Dec., 1972), pp. 573-585. 